\title{
Peranan Pembiayaan Mudhärabah dalam Pengembangan Usaha Mikro Kecil pada KJKS Manfaat

\author{
\begin{tabular}{l|l} 
d_firman09@gmail.com & $\begin{array}{l}\text { VIS Sunan Ampel } \\
\text { Jl. A. Yani 117 Surabaya, Indonesia }\end{array}$
\end{tabular}
} \\ Dini Firmansyah
}

\begin{abstract}
The purpose of this paper is: (1) to find out how to finance mudarabah in KFKS Manfat, and (2) to find out how the role of financing in the development of micro and small businesses in KJKS Benefits. At the end of the paper concludes with two conclusions. First, mud financing a rabah in KJKS Benefit is financing which has the role of cooperation in business between the two parties, namely the first party as the owner of capital, KJKS and the second party manager, the KJKS member and the profits are divided according to the agreement between the two sides. Secondly, the role of mudarabah financing in micro small businesses is as a venture capital with a profit sharing system, using a contract that is in accordance with Islamic sharia or cooperation between sahib al-mal and mudärib, where mud arib is limited by restrictions on the type of business, time and place of business and Determination of the amount of profit sharing is made at the time of the contract and by referring to the profit and loss.
\end{abstract}

Abstrak: Tujuan dari penulisan ini adalah: (1) untuk mengetahui bagaimana pembiayaan mudārabah dalam KJKS Manfat, dan (2) untuk mengetahui bagaimana peranan pembiayaan dalam pengembangan usaha mikro dan kecil pada KJKS Manfaat. Di akhir tulisan ditutup dengan dua kesimpulan. Pertama, pembiayaan mudärabah dalam KJKS Manfaat adalah pembiayaan yang mempunyai peran sebagai kerjasama dalam usaha antara kedua belah pihak, yaitu pihak pertama sebagai pemilik modal yaitu KJKS dan pihak kedua pengelolayaitu anggota KJKS dan keuntungannya dibagi sesuai dengan kesepakatan antara kedua belah. Kedua, peran pembiayaan mudärabah dalam usaha mikro kecil adalah sebagai modal usaha dengan sistem bagi hasil, dengan menggunakan akad yang sesuai dengan syari'ah Islam atau kerjasama antara șahib al-mal dan muḍārib, dimana muḍarib dibatasi dengan batasan jenis usaha, waktu dan tempat usaha dan Penentuan

Al-Qānūn, Jurnal Pemikiran dan Pembaharuan Hukum Islam Vol. 21, No. 2, Desember 2018, ISSN 2088-2688 
besarnya bagi hasil dibuat pada waktu akad dan dengan berpedoman pada untung rugi.

Kata kunci: Pembiayaan muḍārabah, Pengembangan Usaha Mikro dan Kecil,dan KJKS Manfaat Surabaya.

\section{Pendahuluan}

Pembiayaan merupakan aktivitas Koperasi jasa keuangan syariah dalam menyalurkan dananya kepada pihak nasabah yang membutuhkan dana. Pembiayaan sangat bermanfaat bagi bank syari'ah, nasabah, dan pemerintah. Dan memberikan hasil yang paling besar diantara penyaluran dana lainnya yang dilakukan oleh bank syari'ah. Sebelum penyaluran dana melalui pembiayaan, Koperasi jasa keuangan syariah perlu melakukan analisis pembiayaan yang mendalam. ${ }^{1}$

Pada dasarnya, pembiayaan yang disalurkan oleh Koperasi jasa keuangan syariah kepada nasabah merupakan investasi yang dilakukan oleh Koperasi jasa keuangan syariah kepada nasabah. Pembiayaan yang diberikan oleh Koperasi jasa keuangan syariah berfungsi membantu masyarakat dalam memenuhi kebutuhan dalam meningkatkan usahanya. Masyarakat merupakan individu, pengusaha, lembaga, badan usaha dan lain-lain yang membutuhkan dana. Secara perinci pembiayaan memiliki fungsi antara lain:

1. Pembiayaan dapat meningkatkan arus tukar menukar barang jasa.

2. Pembiayaan merupakan alat yang dipakai untuk memanfaatkan midle fund.

3. Pembiayaan sebagai alat pengendali harga.

4. Pembiayaan dapat mengaktifkan dan meningkatkan manfaat ekonomi yang ada. ${ }^{2}$

Berdasarkan Undang-undang No 25 Tahun 1992 pasal 1 ayat 1 Tentang Perkoperasian dirumuskan bahwa"

\footnotetext{
${ }^{1}$ Ismail Nawawi, Perbankan Syari'ah (Jakarta: Kencana, 2011), 105.

${ }^{2}$ Nawawi, 108.
} 
Koperasi adalah badan usaha yang beranggotakan orang atau badan hukum koperasi dengan melandaskan kegiatan berdasarkan prinsip koperasi sekaligus sebagai gerakan ekonomi rakyat yang berdasarkan atas asas kekeluargaan".3

Dan koperasi syari'ah juga memiliki pengertian yang sama yang kegiatan usahanya bergerak di bidang pembiayaan, investasi, dan simpanan sesuai pola bagi hasil (syariah ), atau lebih dikenal dengan koperasi jasa keuangan syariah. $^{4}$

Adapun prinsip dasar koperasi syari'ah adalah menegakkan prinsip-prinsip ekonomi Islam, sebagai berikut: 1. Kekayaan adalah amanah Allah SWT yang tidak dapat dimiliki oleh siapapun secara mutlak.

2. Manusia diberi kebebasan dalam muamalah selama tidak melanggar ketentuan syari'ah.

3. Manusia merupakan wakil Allah dan pemakmur di bumi.

4. Menjunjung tinggi keadilan serta menolak setiap bentuk ribawi dan pemusatan sumber dana ekonomi pada segelintir orang atau sekelompok orang saja. ${ }^{5}$

Oleh karena itu secara garis besar koperasi syari'ah memiliki aturan yang sama dengan koperasi umum, ${ }^{6}$ namun yang membedakannya adalah produk-produk yang ada di koperasi umum diganti dan disesuaikan nama dan

${ }^{3}$ Nafi' Mubarok, Hukum Dagang: Buku Perkuliahan (Surabaya: IAIN Press, 2015), 84.

4 "Profil dan Prinsip Dasar KJKS Manfaat Surabaya," 2012.

5 Nafi' Mubarok, Buku Ajar Mahasiswa: Hukum Asuransi dan Koperasi di Indonesia (Surabaya: Fakultas Syariah IAIN Sunan Ampel, 2013), 140.

6 Seperti hakekat koperasi yang merujuk pada Undang-undang Nomor 25 Tahun 1992 tentang Perkoperasian, bahwa: Koperasi adalah badan usaha yang beranggotakan orangorang atau badan hukum koperasi dengan melandaskan kegiatannya berdasarkan prinsip koperasi sekaligus sebagai gerakan ekonomi rakyat yang berdasarkan asas kekeluargaan. Lihat: Nafi' Mubarok, Buku Diktat Hukum Dagang (Surabaya: Fakultas Syariah dan Hukum Universitas Sunan Ampel, 2016), 81-82. 
sistemnya dengan tuntunan dan ajaran agama Islam. $^{7}$ Sebagai contoh produk jual beli dalam koperasi umum diganti namanya dengan istilah murabahah, produk simpan pinjam dalam koperasi konvensional diganti namanya dengan mudärabah. ${ }^{8}$

Ada tiga landasan koperasi syari'ah yaitu: koperasi syari'ah berlandaskan Pancasila dan Undang-Undang Dasar 1945, koperasi syari'ah berazaskan kekeluargaan, koperasi syari'ah berlandaskan syari'ah Islam yaitu Al-Qur'an dan AsSunnah dengan saling tolong menolong dan saling menguatkan. ${ }^{9}$

Adapun beberapa waktu ketika terjadi perbedaan di masyarakat bank. Setiap akad tentang haramnya bunga bank, terjadinya pro dan kontra membuat masyrakat (terutama masyarakat muslim) bingung utuk mengambil sikap, padahal masyarakat tidak bisa dipisahkan dari bank. ${ }^{10}$ Setiap perekonomian ummat selalu bersentuhan dengan perbankan. ${ }^{11}$ Misalnya ketika menabung harus ke bank, trantfer dan kirim uang juga melalui bank, dan apabila menginginkan modal juga harus ke bank. Hingga muncul suara pertanyaan manakah yang benar dan adakah lembaga

${ }^{7}$ Mubarok, Buku Ajar Mahasiswa: Hukum Asuransi dan Koperasi di Indonesia, 133-34.

8 Admin, "Profil KJKS Manfaat," diakses 22 Juni 2013, kjksmanfaat.blogpot.com/2009/03/.

9 Admin, "Koperasi Syariah," diakses 22 Juni 2013, www.koperasisyariah.com.

${ }^{10}$ Bank merupakan lembaga keuangan yang mempunyai peranan yang strategis dimana kegiatan utama dari perbankan adalah menyerap dana dari masyarakat dan menyalurkan kembali kepada masyarakat. Lihat: Nafi' Mubarok, "Tinjauan Hukum Islam Terhadap Prinsip Bagi Hasil dalam Perbankan,” Maliyah 1, no. 2 (Desember 2011): 178.

${ }^{11}$ Hal ini dikareakan karena pengertian bank sebagaimana dalam Pasal 1 angka1 Undang-undang Perbankan Tahun 1992, yaitu "Bank adalah badan usaha yang menghimpun dana dari masyarakat dalam bentuk simpanan dan menyalurkannya kepada masyarakat dalam rangka meningkatkan taraf hidup rakyat banyak. Lihat: Mubarok, Hukum Dagang: Buku Perkuliahan, 201. 
lain yang dapat dijadikan alternatif pemecahan bagi permasalahn tersebut.

Lembaga yang menerapkan sistem perbank syari'ah merupakan jawaban dan solusi bagi masyarakat muslim yang menginginkan untuk bertansaksi secara aman, mudah dan terjamin kehalalannya. ${ }^{12}$

Adapun lembaga syari'ah Islam sudah ada sejak tahun 1992 dengan berdirinya bank syari'ah pertama di Indonesia yaitu Bank Muamalat Indonesia. Bahkan di tahun 80-an sejak itu banyak berdiri lembaga-lembaga syari'ah yaitu BT (Baitul Tanwil) atau ruah pembiayaan yang dikelolah secara bagi hasil sesuai syari'ah. ${ }^{13}$ Sehingga sekarang banyak bank syari'ah maupun BMT bermunculan di masyarakat. ${ }^{14}$ Dan juga muncul Koperasi Jasa Keuangan syari'ah (KJKS) Manfaat yang merupakan lembaga keuangan berdasarkan prinsip syari'ah Islam yang didukung oleh tenaga yang terampil dan berpengalaman dengan sistem dan program serta siap melayani dalam menangani setiap transaksi perbankan sesuai hukum ekonomi Islam.

Koperasi Jasa Keuangan Syari'ah (KJKS) didirikan dengan maksud agar dapat memberikan pelayanan dan pendampingan kepada masyarakat usaha mikro dan kecil untuk meningkatkan kualitas hidup masyarakat dengan tingkat perekonomian menengah. ${ }^{15}$

12 Rintisan pemikiran ekonomi syariah di Indonesia dimulai pada periode awal 1980-an, melalui diskusi-diskusi dengan tokoh-tokoh Karnaen A. Perwataatmadja, M. Dawam Rahardjo, AM. Saefuddin, dan M. Amien Azis. Lihat: Nafi' Mubarok, "Lembaga Keuangan Syariah sebagai Mustahiqq Zakāh," Jurnal Al-Qānūn 13, no. 2 (Desember 2010): 365.

${ }_{13}$ Pelopornya adalah BMT Bian Insan Kamil. Dalam perkembangannya ternyata BMT mampu memberi warna bagi perekonomian kalangan akar rumput, yakni para pengusaha mikro. Lihat: Mubarok, Buku Ajar Mahasiswa: Hukum Asuransi dan Koperasi di Indonesia, 131. 366.

${ }^{14}$ Mubarok, "Lembaga Keuangan Syariah sebagai Mustaḥiqq Zakāh,"

15 Dalam sistem ekonomi Islam, guna menjamin terwujudnya kemaslahatan individu dan masyarakat maka harus dilandaskan prinsip: 
KJKS Manfaat adalah sebuah lembaga yang telah berbadan hukum dengan Nomor Badan Hukum: 63/BH/XVI.37/2007 Tanggal: 11 April 2007. ${ }^{16}$ Dalam operasionalnya telah memiliki kelengkapan usaha berupa Nomor Pokok Wajib Pajak (NPWP) No. 02.607.444.3606.000. KJKS Manfaat adalah dari anggota dan untuk anggota, sehingga keputusan tertinggi berada pada rapat anggota. KJKS Manfaat mempunyai visi memberikan manfaat dan kesejahteraan kepada anggota, usaha mikro, usaha kecil dan stakeholder. ${ }^{17}$

Adapun program dan kegiatan KJKS Manfaat adalah program pemberdayaan UKM yang mana program binaan kelompok UKM diadakan dua minggu sekali dan KJKS Manfaat juga mewarkan kerjasama dalam model penawaran. Adapun bentuk kerjasama dalam penawaran adalah pembiayaan bagi hasil, bonus dan pelayanan.

Sistem bagi hasil merupakan karakter dari KJKS yaitu sebuah kesepakatan yang dibuat oleh KJKS dengan pihak anggota mengenai bagi hasil tentang keuntungan dan kerugiannya yang diberikan oleh pihak KJKS, dengan mengutamakan prinsip keadilan dan hubungan kerjasama investasi yang harmonis. Bukan sebatas hubungan KJKS dengan anggota, akan tetapi melebihi pada hubungan keluarga yang berkelanjutan. ${ }^{18}$

Dalam prisip ini kedua belah pihak dituntut untuk sunggu-sungguh dan bertanggung jawab dalam menjalankan kewajibannya, sehingga bisa sama-sama menguntungkan

(1) keadilan ekonomi, (2) jaminan social, (3) pemanfaatan sumbersumber daya ekonomi produktif secara efisiensi. Lihat: Atok Syihabuddin, "Etika Distribusi dalam Ekonomi Islam," Jurnal Al-Qānūn 20, no. 1 (Juni 2017): 86.

16 Hal ini tak lepas dari ketentuan dalam Undang-undang Perkoperasian Pasal 9: "Koperasi memperoleh status badan hukum setelah akta pendiriannya disahkan oleh Pemerintah. Lihat: Mubarok, Buku Diktat Hukum Dagang, 86.

${ }^{17}$ Admin, "Profil KJKS Manfaat."

${ }^{18}$ Saifuddin, Wawancara, 25 September 2013, Surabaya. 
dari kedua belah pihak dan tidak berlakunya sistem bunga. Dengan tidak berlakunya sistem bungan berarti tidak ada pembebanan bunga yang berkesinambungan sebagaimana yang terjadi pada lembaga konvensional. Selain itu KJKS juga sangat selektif dan mengedepankan prinsip kehatihatian (prudential) dan mencari usaha yang benar-benar halal, aman dan menguntunngkan. Sebagai mana diketahui bahwa dengan besar tingkat pembiayaan yang disalurkan secara efektif dan efesien akan menambah tingkat tingkat pendapatan yang diperoleh untuk kesejahteraan anggotanya. Dalam praktiknya KJKS Manfaat tetap menggunakan pembiayaan mudärabah dan kesepakatan bersama antara antar pemegang modal (KJKS) dengan pengelola modal (anggota).

\section{Pembiayaan Mudiarabah \\ Pengertian Pembiayaan Muḍhārabah}

Kata mudärabah berasal dari kata darb yang berarti memukul atau berjalan. Pengertian memukul atau berjalan ini maksudnya adalah proses seseorang memukulkan kakinya dalam menjalankan usaha. ${ }^{19}$ Suatu kontrak disebut mudärabah, karena pekerja (mudärib) biasanya membutuhkan suatu perjalanan untuk menjalankan bisnis. ${ }^{20}$

Mudārabah atau qirad termasuk dalam kategori syirkah. Di dalam Al-Quran, kata mudärabah tidak disebutkan secara jelas dengan istilah mudärabah. Al-Quran hanya menyebutkannya secara musytaq dari kata dharaba yang terdapat sebanyak 58 kali. Beberapa ulama memberikan pengertian muḍarabah atau qirạ sebagai berikut:

19 Mubarok, "Tinjauan Hukum Islam Terhadap Prinsip Bagi Hasil dalam Perbankan," 181.

${ }^{20}$ Agustianto, Slide Mata kuliah Fiqih Muamalah (Jakarta: PSTTI-UI, 2008), 83. 
a. Menurut Hanafiyah, mudärabah adalah "Akad syirkah dalam laba, satu pihak pemilik harta dan pihak lain pemilik jasa".

b. Malikiyah berpendapat bahwa mudärabah adalah: "Akad perwakilan, di mana pemilik harta mengeluarkan hartanya kepada yang lain untuk diperdagangkan dengan pembayaran yang ditentukan (mas dan perak)".

c. Imam Hanabilah berpendapat bahwa mudarabah adalah: "Ibarat pemilik harta menyerahakan hartanya dengan ukuran tertentu kepada orang yang berdagang dengan bagian dari keuntungan yang diketahui".

d. Ulama Syafi'iyah berpendapat bahwa mudarabah adalah: "Akad yang menentukan seseorang menyerahakan hartanya kepada orang lain untuk ditijarahkan".

Dari beberapa pengertian di atas dapat ditarik kesimpulan bahwa mudārabah adalah akad kerjasama usaha antara dua pihak di mana pihak pertama adalah pemilik modal (șahib al-mat). Sedangkan pihak lainnya menjadi pengelola modal (mudqarib), dengan syarat bahwa hasil keuntungan yang diperoleh akan dibagi untuk kedua belah pihak sesuai dengan kesepakatan bersama (nisbah yang telah disepakati). Namun bila terjadi kerugian akan ditanggung șahib al-mal. ${ }^{21}$

\section{Dasar Hukum}

Dalil al-Qur'an yang menjelaskan tentang mudiarabah terdapat dalam QS. al-Muzzammil (73): 20, yang artinya: "Sesungguhnya Tuhanmu mengetahui bahwasanya kamu berdiri (sembahyang) kurang dari dua pertiga malam, atau seperdua malam atau sepertiganya dan (demikian pula) segolongan dari orang-orang yang bersama kamu. dan Allah menetapkan ukuran malam dan siang. Allah mengetahui bahwa kamu sekali-kali tidak dapat

${ }^{21}$ Mubarok, Buku Ajar Mahasiswa: Hukum Asuransi dan Koperasi di Indonesia, 140. 
menentukan batas-batas waktu-waktu itu, Maka Dia memberi keringanan kepadamu, karena itu bacalah apa yang mudah (bagimu) dari Al Quran. Dia mengetahui bahwa akan ada di antara kamu orang-orang yang sakit dan orang-orang yang berjalan di muka bumi mencari sebagian karunia Allah dan orang-orang yang lain lagi berperang di jalan Allah, Maka bacalah apa yang mudah (bagimu) dari Al Quran dan dirikanlah sembahyang, tunaikanlah zakat dan berikanlah pinjaman kepada Allah pinjaman yang baik. dan kebaikan apa saja yang kamu perbuat untuk dirimu niscaya kamu memperoleh (balasan) nya di sisi Allah sebagai Balasan yang paling baik dan yang paling besar pahalanya. dan mohonlah ampunan kepada Allah; Sesungguhnya Allah Maha Pengampun lagi Maha Penyayang." 22

Juga dalam QS. al-Baqarah (2): 197, yang artinya: "Tidak ada dosa bagimu untuk mencari karunia (rezki hasil perniagaan) dari Tuhanmu. Maka apabila kamu telah bertolak dari 'Arafat, berdzikirlah kepada Allah di Masy'arilharam dan berdzikirlah (dengan menyebut) Allah sebagaimana yang ditunjukkan-Nya kepadamu; dan Sesungguhnya kamu sebelum itu benar-benar Termasuk orang-orang yang sesat." 23

Selain itu terdapat hadits riwayat Imam Ibnu Majah, yaitu:

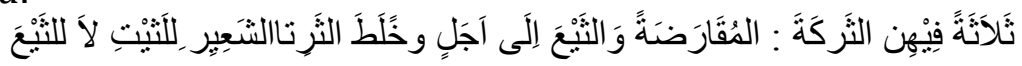
"Tiga macam mendapat barakah: (1) muqāraḍah/ muḍärabah, (2) jual beli secara tangguh, dan (3) mencampur gandum dengan tepung untuk keperluan rumah bukan untuk dijual."

Di samping dalil Qur'an dan dalil Hadist di atas, para ulama juga berlandaskan pada praktik mudharabah yang dilakukan sebagian sahabat, sedangkan sahabat lain tidak membantahnya. Bahkan harta yang dilakukan secara

22 Departemen Agama Republik Indonesia, Al-Quran dan Terjemahnya, Vol 1 (Semarang: Karya Toha Putra, 1998), 576.

${ }^{23}$ Departemen Agama Republik Indonesia, 32. 
mudärabah itu di zaman mereka kebanyakan adalah harta anak yatim. Oleh sebab itu berdasarkan dalil Qur'an, Hadist, dan praktik para sahabat, para ulama fiqih menetapkan bahwa akad mudabah apabila telah memenuhi rukun dan syaratnya maka hukumnya adalah boleh.

\section{Jenis-Jenis Pembiayaan Muḍāabah} yaitu: ${ }^{24}$

Pembiayaan mudăarabah terbagi menjadi dua jenis

a. Mudärabah muțlaqah

Transaksi mudärabah muthlaqah adalah bentuk kerjasama antara șahib al-mal dan mudarib yang cakupannya sangat luas dan tidak dibatasi oleh spesifikasi jenis usaha, waktu dan daerah bisnis.

b. Mudärabah muqayyadah

Transaksi mudārabah muqayyadah adalah bentuk kerja sama antara șahib al-mal dan mudarib, dimana mudarib dibatasi dengan batasan jenis usaha, waktu dan tempat usaha.

\section{Rukun dan Syarat Mudārabah}

Akad mudärabah harus ada syarat maupun rukun yang harus dipenuhi. ${ }^{25}$ Adapun rukun mudārabah adalah sebagai berikut:

a. Orang yang berakad.

b. Mempunyai modal.

c. Keuntungan.

d. Kerja.

e. Akad.

Terdapat beberapa syarat dari akad Muḍarabah, sebagai berikut:

${ }^{24}$ Mubarok, "Tinjauan Hukum Islam Terhadap Prinsip Bagi Hasil dalam Perbankan," 185.

${ }^{25}$ Nasroen Haroen, Fiqih Muamalah (Jakarta: Gaya Media Pratama, 2000), 177. 
a. Syarat yang berkaitan dengan orang yang melakukan transaksi, harus orang yang cakap bertindak atas nama hukum dan cakap diangkat sebagai wakil.

b. Syarat yang berkaitan dengan modal:

1) Syarat berbentuk uang.

2) Jelas jumlahnya.

3) Tunai.

4) Diserahkan semua kepada pedagang. ${ }^{26}$

c. Syarat yang berkaitan dengan keuntungan, yang mana pembagian keuntungan harus jelas dan masing-masing pekerja maupun pemilik modal mempunyai hak dalam sistem mudärabah, antara masing-masing pekerja maupun pemilik modal mempunyai hak yang ditetapkan bersama.

Adapun hak-hak tersebut adalah: ${ }^{27}$

a. Hak pekerja.

1) Seoran pekerja mendapat keuntungan sesuai dengan keterampilannya.

2) Modal yang digunakan adalah sebagai amanah yang wajib dijaga, sekiranya terjadi kerugian, maka tidak ada ganti rugi dan tuntunan.

3) Kedudukan pekerja adalah sebagai agen, yang dapat menggunakan modal atas persetujuan pemilik modal.

4) Apabila ada keuntugan, maka dia berhak mendapat imbalanatas usaha yang tenaganya, sekiranya usaha itu rugi, dia berhak mendapatkan upah.

5) Apabila pekerja itu tidak bertugas di daerahnya sendiri, seperti kota lain yang jauh, maka diapun berhak mendapatkan upah.

6) Hak pemilik modal

${ }^{26}$ Mubarok, "Tinjauan Hukum Islam Terhadap Prinsip Bagi Hasil dalam Perbankan," 182.

${ }^{27}$ M. Ali Hasan, Berbagai Macam Transaksi dalam Islam (Jakarta: Raja Grafindo Persada, 2003), 176. 
1) Keuntungan dibagi dihadapan pemilik modal dan pekerja pada saat pekerja mengambil bagian keuntungannya.

2) Pekerja tidak boleh mengambil bagiannya tanpa kehadiran pemilik modal.

\section{Usaha Mikro dan Kecil}

Menurut UU No. 20 Tahun 2008 Tentang Usaha Mikro, Kecil, dan Menengah disebutkan bahwa Usaha Mikro adalah usaha produktif milik orang perorangan dan/atau badan usaha perorangan yang memenuhi kriteria usaha mikro sebagaimana diatur dalam undang-undang ini.

Adapun kriteria usaha mikro yang dapat dilihat pada Pasal 6 ayat (1), disebutkan bahwa: ${ }^{28}$

a. Usaha mikro memiliki kekayaan bersih paling banyak Rp 50.000.000,00 (lima puluh juta rupiah) tidak termasuk tanah dan bangunan tempat usaha;

b. Memiliki hasil penjualan tahunan paling banyak $\mathrm{Rp}$ 300.000.000,00 (tiga ratus juta rupiah).

Sedangkan Usaha Kecil adalah usaha ekonomi produktif yang berdiri sendiri, yang dilakukan oleh orang perorangan atau badan usaha yang bukan merupakan anak perusahaan atau bukan cabang perusahaan yang dimiliki, dikuasai, atau menjadi bagian baik langsung maupun tidak langsung dari usaha menengah atau usaha besar yang memenuhi kriteria usaha kecil sebagaimana dimaksud dalam undang-undang ini.

\section{Pembiayaan Usaha Mikro Kecil Pada KJKS Manfaat Profil KJKS Manfaat}

KJKS Manfaat adalah sebuah lembaga yang berdiri pada tahun 2007 dengan badan hukum No.63/BH/XVI.37/2007 tanggal 11 April 207 berkantor di Ruko Graha Indah Kav A-7, jln. Gayung Kebonsari No 46

${ }^{28}$ Undang-undang No 20 Tahun 2008 Tentang Usaha Mikro, Kecil, dan Menengah. 
Surabaya. Dalam operasionalnya telah memiliki kelengkapan usaha berupa Nomor Pokok Wajib Pajak (NPWP) No 02.607.444.3-606.000, KJKS Manfaat adalah anggota dari anggota, sehingga keputusan tertiggi berada pada rapat anggota $\mathrm{KJKS}^{29} \mathrm{KJKS}$ berlaku untuk semua orang atau universal dan siapa saja dapat memanfaatkan jasa keuangan koperasi syariah dan sistem syariah telah memberikan manfaat bagi banyak kalangan.

Adapun visi dari KJKS Manfaat yaitu:" "Memberikan manfaat dan kesejahteraan kepada anggota, usaha mikro, usaha kecil dan stakeholder".

Sedangkan misinya adalah:

a. Mengembangkan lembaga keuangan Islam yang kuat, terpercaya dan memiliki jaringan yang luas.

b. Memiliki sumber daya insani (SDM) yang profesional, cerdas, inovatif, dan bertaqwa.

c. Memberikan kepercayaan kepada mitra kerja dalam bekerja dan perasaan aman bagi semua kalangan yang menikmati jasa lembaga ini.

d. Berkomitmen tinggi menjadikan lembaga keuangan yang murni sesuai syariah dan berorientasi kepada usaha mikro kecil. ${ }^{31}$

\section{Pembiayaan Khusus di KJKS Manfaat}

Pembiayaan di KJKS Manfaat bisa dikelompokkkan sebagai berikut:

a. Pembiayaan produktif

1) Mudärabah (bagi hasil)

2) Musyärakah (modal kerja)

b. Pembiyaan konsumtif

1) Murabahah (jual beli)

2) Ijarah (sewa)

\footnotetext{
${ }^{29}$ KJKS Manfaat, “Proposal kerjasama KJKS Manfaat," 2012.

30 "Profil dan Prinsip Dasar KJKS Manfaat Surabaya."

31 "Profil dan Prinsip Dasar KJKS Manfaat Surabaya."
} 
Sedangkan produk-produk simpanan dan pembiayaan dari KJKS Manfaat adalah sebagai berikut:

a. Produk-produk simpanan

1) Simpanan "Ummat".

2) $\mathrm{Si}$ "Quat" (Simapanan Kurban Dan Aqiqah Bermanfaat).

3) Salimah (Simpanan Walimatul Urs'y).

4) Si "Pintar" (Simpanan Pendidikan Pelajar).

5) $\mathrm{Si}$ "Arafah" (Simpanan Hajji Dan Umrah).

6) Si "Mudah" (Simpanan Berjangka Mudāarabah).

b. Produk-produk pembiayaan "Manfaat"

1) Ceria (Creatif Wirausaha Rumah Tangga).

2) Puas (Pengusaha dan Pegawai Sukses).

3) M-Mega Pro (Manfaat Mega Proyek).

4) M- 90 Bisa (Manfaat - 90 Hari Bisa).

\section{Pembiayaan Usaha Mikro Kecil Pada KJKS}

Pembiayaan UMK merupakan pembiayaan yang disediakan oleh Koperasi jasa keuangan syariah kepada pengusaha kecil dan mikro serta masyarakat yang berpenghasilan rendah yang tidak terlayani oleh lembaga keuangan formal dan yang telah berorientasi pasar untuk tujuan bisnis.

Program dan kegaiatan pada KJKS Manfaat adalah. ${ }^{32}$

a. Program pelatihan.

1) Pelatihan mengenal ekonomi syariah.

2) Pelatihan menegemen ekonomi syariah.

3) Pelatihan entrepeneurship UKM LAZ Al-Mabrur Surabaya.

b. Program pemberdayaan

1) Pemberdayaan kerjasama dengan BAZ Jatim

2) Pemberdayaan UKM LAZ Al-Mabrur Depag Jatim kerjasama dengan microfin cabang surabaya

c. Program pembinaan

${ }^{32}$ Saifuddin, Wawancara, 25 September 2013. 
Pembinaan kelompok UKM dan anggota setiap dua minggu sekali. Adapun kerjasama antara KJKS Manfaat dengan lembaga salah satunya adalah:

\begin{tabular}{|l|l|}
\hline Nama Lembaga & Bentuk Kerjasama \\
\hline BAZ Jatim & $\begin{array}{l}\text { Penyaluran modal bergulir untuk } \\
\text { usaha kecil dan mikro }\end{array}$ \\
\hline Depag Jatim & $\begin{array}{l}\text { Penyaluran modal bergulir untuk } \\
\text { usaha kecil dan mikro }\end{array}$ \\
\hline Microfin & Modal penyertaan \\
\hline
\end{tabular}

Adapun daerah program binaan KJKS adalah:

1) Surabaya, meliputi: Dukuh Kupang, Ketintang, Banyu Urip, Sukolilo dan Sawahan.

2) Sidoarjo, meliputi: Candi dan Krian.

3) Gresik

Program jangka panjang KJKS Manfaat adalah: ${ }^{33}$

a. Meningkatkan jumlah pembiayaan melalui produk jasa dan usaha sesuai dengan sistem syariah.

b. Mengembangkan program pemberdayaan UKM melalui sistem renteng.

Pemberdayaan Usaha Mikro Kecil menengah (UMKM) merupakan salah satu alternatif yang dipilih pemerintah dalam upaya mengurangi pengangguran, mengentas kemiskinan dan pemerataan pendapatan. Pembangunan dan pertumbuhan UMKM merupakan nomer satu penggerak bagi pembangunan dan pertumbuhan ekonomi suatu negara. Perkembangan UMKM yang baik maka akan membawa kemajuan bagi perekonomian suatu negara.

Untuk memberdayakan UMKM diperlukan peranan pemerintah, lembaga- lembaga keuangan dan pelaku usaha. Peranan pemerintah di sini adalah memutuskan kebijakankebijakan yang memberikan iklim kondusif bagi dunia usaha sedangkan lembaga keuangan disini jelas sebagai perantara keuangan untuk mengoptimalkan pemerdayaan UMKM dan pelaku usaha itu sendiri memiliki peranan pokok bagi

\footnotetext{
${ }^{33}$ Saifuddin.
} 
perkembangan UMKM karena pelaku usaha memiliki potensi yang kuat dalam pertumbuhan UMKM.

Adapun beberapa kendala dan kesulitan yang dihadapi dalam pengembangan UMKM yaitu: "Keterbatasan modal usaha, keterbatasan Sumber Daya Manusia (SDM), keterbatasan teknologi, keterbatasan bahan baku dan kesulitan pemasaran". Untuk mengatasi keterbatasan modal, sering kali para pengusaha UMKM meminjam dari lembaga keuangan dengan bunga yang cukup tinggi.

Proses pembiayaan melalui sistem renteng yaitu melalui musyawarah dalam kelompok, selain menerapkan sistem renteng, perlunya pembinaan dan pendampingan kepada mmasyarakat tentang membuka suatu usaha. Program pemberdayaan, pembinaan dan pendampingan masyarakat ini terkait dengan cara menemukan peluang yang baik, menejemen, dan keterampilan dalam mengelola usaha dan sebagainya agar permasalahan yang sering dihadapi oleh UKM dapat berkurang atau teratasi. Meningkatkan kesadaran masyarakat dalam mengembangkan UKM lebih utama karena masyarakat sebagai pelaku usaha tersebut sehingga keberhasilan pengembangan UKM berawal dari sini. ${ }^{34}$

Dalam pemerdayaan UKM perlu diberikan motivasi dan manfaat dari berbagai peluang-peluang dan fasilitas yang diberikan dari berbagai pihak (stakeholder yang lain) karena tanpa partispasi UKM secara individu maupun kelompok akan berakibat gagalnya usaha pemerdayaan yang dilakukan".

Menciptakan suatu UMK memang tidak mudah diperlukan modal yang cukup dan keterampilan dalam mengelola usaha. Sehingga memberikan kemudahan pelaku usaha untuk mengembangkan usahanya. ${ }^{35}$

Sebelum adanya program UKM masyarakat sulit mengembangkan usahanya dan sulit untuk mengakses dana

\footnotetext{
${ }^{34}$ Saifuddin, Wawancara, 15 Januari 2014, Surabaya.

${ }^{35}$ Saifuddin, Wawancara, 25 September 2013.
} 
atau modal akan tetapi adanya program UKM yang diadakan oleh KJKS maka dapat meningkatkan perekonomian masyarakat dan mampu memperluas lapangan kerja dan memberikan pelayanan ekonomi secara luas kepada masyarakat, sehingga masyarakat dapat mengembangkan usahanya lebih besar lagi dan bisa mengakses dana atau modal tanpa proses yang rumit dan halal untuk mengembangkan usaha atau membuka usaha baru. Dan program yang diberikan oleh KJKS Manfaat, mampu memberikan kesejahteraan bagi para anggota UKM dan bisa memberikan manfaat bagi usaha-usaha mikro dan kecil untuk lebih maju dan mandiri, serta membuka, membimbing dan memperdayakan warga disekitarnya untuk usaha sendiri agar mampu memperbaiki kualitas hidupnya. Dan KJKS mempunyai peran penting pada peningkatan pendapatan anggota masyaratakat di sekitarnya, karena dengan adanya KJKS Manfaat masyarakat kecil yang kekurangan dana untuk melanjutkan usahana dengan mudah dan mereka mendapatkan pinjaman modal dalam bentuk pembiayaan tanpa harus mengembalikan bunga yang terlalu tinggi.

Sedangkan untuk prosedur pengajuan pembiayaan modal kerja yang diberikan oleh KJKS kepada anggota UMK atau yang lainnya sangatlah mudah dan tidak rumit, dan persyaratan administratifnya untuk pengajuan individu atau kelompok sangatlah mudah.

\section{Analisis Pembiayaan Muḍārabah Pada KJKS Manfaat}

Lembaga keuangan syari'ah merupakan lembaga Islam yang memiliki kegiatan pembiayaan yang sering disebut akad. Salah satunya adalah akad pembiayaan mudärabah, yaitu pembiayaan yang mempunyai peran sebagai akad kerja sama usaha atara dua belah pihak, dimana pihak pertama sebagai șahib al-mal yang menyediakan seluruh modalnya, sedangkan pihak kedua sebagai muḍārib (pengelola). 
Kemudian keuntungan usaha tersebut di bagi menurut kesepakatan awal yang dituangkan dalam kontrak. Dalam Hadist riwayat Ibnu Majah di jelaskan juga pembiayaan yang mendapatkan berkah yaitu yang Artinya "Tiga macam mendapat barakah: muqaradhah/ mudharabah, jual beli secara tangguh, mencampur gandum dengan tepung untuk keperluan rumah bukan untuk dijual". (HR.Ibnu Majah).

Jenis-jenis pembiayaan mudärabah ada dua macam yaitu pembiayaan mudärabah muthalaqah, dan mudarabah muqayyadah selain jenis-jenis pembiayaan mudarabah ada juga rukun dan syarat mudārabah yang harus dipenuhi yaitu akad, orang yang berakad dan mempunyai modal sedangkan syaratnya adalah syarat yang berkaitan dengan orang yang melakukan transaksi, syarat yang berkaitan dengan modal, dan syarat yang berkaitan dengan keuntungan. Dan manfaat pembiayaan mudärabah salah satunya yaitu bahwasanya prinsip bagi hasil dalam mudārabah berbeda dengan prinsip bunga, dimana bank akan menagih pembiayaan anggota suatu jumlah bunga tetap berapapun keuntungan yang dihasilkan anggota sekalipun merugi dan terjadi krisis.

Terdapat pembiayaan pada KJKS Mafaat yang merupakan Pembiayaan Berdasarkan Prinsip Bagi Hasil (Profit Sharing). Sistem ini adalah suatu sistem yang meliputi tata cara pembagian hasil usaha antara penyedia dana dengan pengelola dana. Pembagian hasil usaha ini dapat terjadi antara KJKS dengan penyimpan dana, maupun antara KJKS dengan anggota penerima dana. Bentuk produk yang berdasarkan prinsip ini adalah:

1. Al-musyārakah, dimana dana dari KJKS merupakan bagian dari modal usaha anggota dengan kesepakatan bahwa keuntungan dan risiko akan ditanggung bersama.

2. Al-mudärabah, dimana seluruh modal usaha sepenuhnya dari KJKS dan keuntungan yang diperoleh dibagi sesuai dengan nisbah yang disepakati. 
Lebih jauh prinsip mudarabah dapat dipergunakan sebagai dasar baik untuk produk pendanaan (simpanan dan deposito) maupun pembiayaan, sedangkan musyarakah lebih banyak untuk pembiayaan atau penyertaan. ${ }^{36}$

KJKS Manfaat dalam menjalankan programnya mempunyai bermacam-macam produk yang disediakan untuk masyarakat. Salah satunya adalah produk simpan pinjam dalam bentuk pembiayaan, yakni pembiayaan mudārabah yang diberikan keberbagai kalangan baik sektor pertanian, industri, perdagangan, nelayan serta para pedagang kecil yang ingin mengembangkan dan meningkatkan produktivitas usahanya. Dan produktivitas dalam menjalankan sebuah usaha perlu ditingkatkan karena merupakan faktor terpenting dalam suatu usaha yang dijalankan agar tetap dapat tumbuh dan berkembang sesuai dengan perkembangan zaman.

Oleh karena itu, dalam rangka mensejahterakan dalam meningkatkan pendapatan masyarakat khususnya usaha kecil untuk meningkatkan kegiatan ekonominya serta memperkuat daya saingnya. KJKS Manfaat direncanakan sebagai gerakan nasional dalam rangka memberdayakan masyarakat sampai lapisan bawah.

Awal berdirinya KJKS Manfaat memulai operasionalnya dengan bermodalkan Rp. 13.000.000,-akhir tahun 2007 total modal bertambah sebesar Rp. 46.749.721,sampai dengan tahun 2011 jumlah modal KJKS Manfaat terus meningkat sebesar Rp.683.404.040. Akad pembiayaan mudärabah menunjukkan adanya perkembangan dari tahun ke tahun, jumlah nasabah yang melakukan pembiayaan mudāarabah dari tahun ketahun ada peningkatan, hal ini menunjukan bahwa perhatian yang diberikan KJKS manfaat dalam memberikan pembiayaan terhadap usaha kecil dan menengah dapat dikatakan mengalami kemajuan yang cukup baik.

${ }^{36}$ Hendi Suhendi, Fiqih Muamalah (Jakarta: Raja Grafindo Persada, 2010), 97. 
Dari pemaparan di atas, dapat dilihat bahwa program pembiayaan mudärabah bagi masyarakat dan pelaku usaha lainnya dapat dikatakan mengalami kemajuan, sebab dengan adanya pembiayaan tersebut maka para pelaku usaha dapat memperoleh keuangan tersendiri. Karena dengan adanya pembiayaan mudärabah masyarakat tidak harus meminjam pada rentenir yang memberikan pinjaman dengan bunga yang relatif tinggi dan dapat memberatkan mereka. Pembiayaan mudärabah juga dilakukan agar semua masyarakat yang menjalankan pembiayaan tersebut dapat meningkatkan perekonomiannya.

Dengan pembiayaan mudärabah yang ada di KJKS diharapkan meningkatkan pengembangan usaha salah satunya dalam pengembangan usaha mikro dan kecil melalui penjualan peningkatan tenaga kerja, penambahan jumlah anggota dll disetiap tahunnya dimana pengembangan tersebut dapat membawa dampak pada perkembangan KJKS Manfaat.

\section{Analisis Peran Pembiayaan Usaha Mikro dan Kecil Pada KJKS Manfaat}

Adapun program KJKS adalah program usaha mikro kecil dan menengah yaitu program pelatihan, program pemberdayaan dan program pembinaan, yang termasuk program binaan KJKS yang menawarkan kerjasama dalam bentuk penawaran salah satunya adalah pembiayaan.

Dengan adanya pembiayaan yang ada di KJKS Manfaat yang diberikan kepada usaha kecil dan menengah diharapkan dapat memperlancarkan perekonomian usaha kecil dan menengah dan mampu menekan terjadinya inflasi karena tidak adanya ketetapan bunga yang harus dibayarkan, sehingga dapat membangkitkan motivasi usaha kecil untuk bisa lebih maju. Peranan pembiayaan usaha mikro dan kecil pada KJKS Manfaat adalah yang mana usaha mikro dan kecil itu sendiri program dari KJKS Manfaat, dan dengan adanya program pembiayaan usaha mikro dan kecil 
yang diadakakan oleh KJKS akan meningkatkan perekonomian masyarakat dan mengembangkan usahanya terutama pada usaha kecil dan menengah. Dan daerah program binaan KJKS Manfaat meliputi daerah Surabaya, Sidoarjo dan Gresik dan KJKS mengadakan program bersama UKM Kanwil Depag, UKM Asrama Haji dan UKM BAZ Jatim

Oleh karena itu, keberadaan KJKS Manfaat sebagai salah satu solusi ekonomi yang operasionalnya sesuai dengan prinsip syariah, yang mana dapat menyediakan modal yang relatif terjangkau, syarat yang mudah, dan prosedur yang mudah, cepat dan tepat, sehingga dapat menjadi salah satu solusi untuk memberikan pinjaman modal kepada para anggota yang membutuhkan. Mudah karena tanpa persyaratan surat-surat yang menyulitkan, dan cepat karena pengambilan dana yang di perlukan sewaktu waktu dapat diambil tanpa harus menunggu proses yang lama.

Dengan adanya program UKM, KJKS dapat meningkatkan perekonomian masyarakat dan mampu memperluas lapangan kerja dan memberikan pelayanan ekonomi secara luas kepada masyarakat, sehingga masyarakat dapat mengembangkan usahanya lebih besar lagi dan bisa mengakses dana atau modal tanpa proses yang rumit dan halal untuk mengembangkan usaha atau membuka usaha baru. Dan program yang di berikan oleh KJKS Manfaat, mampu memberikan kesejahteraan bagi para anggota UKM dan bisa memberikan manfaat bagi usahausaha mikro dan kecil untuk lebih maju dan mandiri, serta membuka, membimbing dan memperdayakan warga disekitarnya untuk usaha sendiri agar mampu memperbaiki kualitas hidupnya. ${ }^{37}$

Dari pejelasan diatas peranan pembiayaan usaha mikro dan kecil pada KJKS Manfaat akan meningkatkan

${ }^{37}$ Saifuddin, Wawancara, 15 Januari 2014. 
perekonomian masyarakat dan mengembangkan usahanya terutama pada usaha kecil dan menengah.

Dalam KJKS terdapat program mengembangkan pemberdayaan melalui sitem renteng yaitu dengan melalui musyawarah bersama dalam kelompok dalam kepentingan dan pengampilan keputusan. Sistem tanggung renteng pada KJKS Manfaat Surabaya meliputi:

1. Sistem renteng dalam proses pengambilan keputusan.

2. Sistem renteng dalam masalah finansial (simpanan dan pengelolaan keuntungan).

3. Sistem renteng dalam menghadapi resiko usaha.

4. Sistem renteng dalam memikul beban organisasi terutama dalam menyangkut masa depan KJKS.

Sistem tanggung renteng akan lebih mudah dipahami dalam contoh yang sederhana, misalnya sebuah koperasi terdiri dari beberapa kelompok dan satu kelompok terdiri dari 20 orang kemudian salah satu anggota membutuhkan dana dan dia ingin meminjam uang dari koperasi. Maka kedua puluh orang anggota kelompok tersebut bermufakat untuk menyetujui atau tidak. Merumuskan aturan pengembalian bentuk cicilan disebut dengan tingkat resiko dan keuntungan bersama. Cara ini sangat menarik, mengingat adanya otonomi wewenang penentuan anggota yang berhak mendapatkan pinjaman dana. Karena para anggota kelompoklah yang lebih mengetahui kebutuhan dan kesanggupan anggota dalam mempertanggung jawaban dana yang dipinjam.

Jika karena suatu hal anggota yang meminjam tadi tidak dapat membayar cicilan maka sisilan itu akan di tanggung bersama oleh seluruh anggota kelompok tersebut sehingga tidak ada penunggakan cicilan pada koperasi.

Didalam kelompok tanggung renteng harus ada seorang penanggung jawab yang bertugas mengkoordinir dan sebagai fasilitator terselenggaranya pertemuan kelompok serta bertanggung jawab atas lengkap tidaknya jumlah angsuran yang disetorkan ke koperasi. Pertemuan 
kelompok secara rutin menjadi hal yang wajib karena bagaimana bisa muncul jiwa kebersamaan bila diantara anggota tidak terjadi interaksi dan kemauan saling menanggung tidak akan timbul tanpa adanya jiwa kebersamaan.

\section{Penutup}

Berdasarkan uraian yang dipaparkan sebelumnya, maka bisa diambil kesimpulan sebagai berikut:

1. Pembiayaan muḍarabah dalam KJKS Manfaat adalah pembiayaan yang mempunyai peran sebagai kerjasama dalam usaha antara kedua belah pihak, yaitu pihak pertama sebagai pemilik modal yaitu KJKS dan pihak kedua pengelolayaitu anggota KJKS dan keuntungannya dibagi sesuai dengan kesepakatan antara kedua belah.

2. Peran pembiayaan mudarabah dalam usaha mikro kecil adalah sebagai modal usaha dengan sistem bagi hasil, dengan menggunakan akad yang sesuai dengan syari'ah Islam atau kerjasama antara șahib al-mal dan muḍarib, dimana mudarib dibatasi dengan batasan jenis usaha, waktu dan tempat usaha dan Penentuan besarnya bagi hasil dibuat pada waktu akad dan dengan berpedoman pada untung rugi.

\section{Daftar Pustaka}

Admin. "Koperasi Syariah." Diakses 22 Juni 2013. www.koperasisyariah.com.

- - . "Profil KJKS Manfaat." Diakses 22 Juni 2013. kjksmanfaat.blogpot.com/2009/03/.

Agustianto. Slide Mata kuliah Fiqih Muamalah. Jakarta: PSTTI-UI, 2008.

Departemen Agama Republik Indonesia. Al-Quran dan Terjemahnya. Vol 1. Semarang: Karya Toha Putra, 1998.

Haroen, Nasroen. Fiqih Muamalah. Jakarta: Gaya Media Pratama, 2000.

Hasan, M. Ali. Berbagai Macam Transaksi dalam Islam. Jakarta: Raja Grafindo Persada, 2003.

KJKS Manfaat. “Proposal kerjasama KJKS Manfaat,” 2012. 
Mubarok, Nafi'. Buku Ajar Mahasiswa: Hukum Asuransi dan Koperasi di Indonesia. Surabaya: Fakultas Syariah IAIN Sunan Ampel, 2013.

- - - Buku Diktat Hukum Dagang. Surabaya: Fakultas Syariah dan Hukum Universitas Sunan Ampel, 2016.

- - - Hukum Dagang: Buku Perkuliahan. Surabaya: IAIN Press, 2015.

- - . "Lembaga Keuangan Syariah sebagai Mustahiqq Zakāh." Jurnal Al-Qānün 13, no. 2 (Desember 2010).

- - - "Tinjauan Hukum Islam Terhadap Prinsip Bagi Hasil dalam Perbankan." Maliyah 1, no. 2 (Desember 2011).

Nawawi, Ismail. Perbankan Syari'ah. Jakarta: Kencana, 2011.

"Profil dan Prinsip Dasar KJKS Manfaat Surabaya," 2012.

Saifuddin. Wawancara, 25 September 2013. Surabaya.

-_- Wawancara, 15 Januari 2014. Surabaya.

Suhendi, Hendi. Fiqih Muamalah. Jakarta: Raja Grafindo Persada, 2010.

Syihabuddin, Atok. "Etika Distribusi dalam Ekonomi Islam." Jurnal Al-Qänün 20, no. 1 (Juni 2017). 